"Chernihiv Colleguim"

ORCID 000-002-0597-6489

elenakolesnyk2017@gmail.com

\title{
AN ALTERNATIVE MODEL OF TOTALITARIAN SOCIETY (THROUGH THE EXAMPLE OF LEIGH BRACKETT'S “BOOK OF SKAITH”)
}

The purpose of the research is to go beyond the strict borders of the genre of anti-utopia and to study the depiction of dystopic social system in a work of the science fiction. The main methods are hermeneutics and the comparative analysis. The scientific novelty. For the first time Leigh Brackett's work is researched as an example of sociological and culturological modelling with considerable prognostic potential. Conclusion. In Brackett's "The Book of Skaith" we see not a typical for anti-utopia "island" society, but a whole planet. This implies a whole new level of complexity. The author shows how the changes in environment influence different interconnected societies. This modelling of civilization under pressure can be seen as an implicitly-culturological study of political, social and cultural dynamics. An important ethical topic concerns the degradation of the best ideological principles if they are not adapted to the changing reality. The image of society, where social programs breed a considerable strata of people, who never worked is disturbingly relevant. Almost all depicted social groups develop such protective reaction to the crisis, as the search for oblivion. Brackett shows different variants of escaping from the unbearable knowledge of the impending catastrophe: hedonistic attempts of "living in a moment", totalitarian religions etc. Even such intellectual activity as studying history can become an obsessive immersion in the past as a way of escaping the present. That is why "The Book of Skaith" can be viewed as a warning about the consequences of some tendencies of the contemporary (late XX - early XXI ct.) civilization. In this it differs from many anti-utopias, whose futuristic entourage masks the habit of depiction of the already well-known social ills, and in the forms more typical for the first half of the XX ct., than for our own days.

Key words: anti-utopia; science fiction; totalitarianism; Leigh Brackett

Колесник Олена Сераіївна, доктор культурології, доцент, профресор кафредри фрілософрії та культурології Національного університету «Чернігівський колегіум» імені Т.Г.Шевченка

Альтернативна модель тоталітарного суспільства (на прикладі «Книги Скейту» Лі Брекет)

Мета дослідження - вийти за межі кордонів жанру антиутопії та дослідити зображення дистопічної соціальної системи в творі наукової фантастики. Основними методами є герменевтика та компаративний аналіз. Наукова новизна. Вперше твір Лі Брекет досліджується в якості зразка соціологічного та культурологічного моделювання зі значним прогностичним потенціалом. Висновки. В «Сазі про Скейт» Л. Брекет зображено не звичайний для антиутопії «острівний» соціум, а цілу планету, що передбачає принципово новий рівень складності. Авторка демонструє, як зміни в навколишньому середовищі впливають на різні взаємопов'язані суспільства. Таке моделювання цивілізації, яка знаходиться «під тиском» може розглядатися як імпліцитно-культурологічне дослідження політичної, соціальної та культурної динаміки. Важлива етична тема стосується деградації найкращих ідеологічних принципів, якщо вони більше не відповідають реальності, яка змінилася. Образ суспільства, в якому соціальні програми формують значний прошарок людей, які ніколи не працювали, передбачає одну з проблем сучасної цивілізації. Практично в усіх зображених в творі соціальних групах розвивається така захисна реакція на кризу як пошуки забуття. Брекет показує різні варіанти втечі від нестерпного знання про неминучу катастрофу: гедоністичні спроби «жити однією хвилиною», тоталітарні релігії тощо. Навіть така інтелектуальна діяльність як вивчення історії може перетворитися в нав'язливе занурення у минуле як засіб втечі від теперішнього та майбутнього. Таким чином, «Книга Скейту» може розглядатися як попередження про те, до чого можуть привести деякі тенденції, властиві сучасній (кінець XX - початок XXI ст.) цивілізації, що відрізняє ії від багатьох антиутопій, чий футуристичний антураж маскує схильність описувати вже добре відомі соціальні вади, причому у формах, властивих скоріше першій половині XX ст., ніж нашим дням.

Ключові слова: антиутопія; наукова фантастика; тоталітаризм; Лі Брекет.

Колесник Елена Сергеевна, доктор культурологии, доцент, профрессор кафедры фрилософии и культурологии Национального университета «Черниговский коллегиум» имени Т.Г.Шевченко

Альтернативная модель тоталитарного общества (на примере «Саги о Скейте» Ли Брекетт

Цель исследования - выйти за пределы жанровых границ антиутопии и исследовать изображение дистопической социальной системы в произведении научной фантастики. Основными методами являются герменевтика и компаративный анализ. Научная новизна. Впервые произведение Ли Брекетт исследуется в качестве образца социологического и культурологического моделирования с значительным прогностическим потенциалом. Выводы. В «Саге о Скейте» Л. Брекетт изображается не обычный для антиутопии «островной» социум, а целая планета, что предполагает принципиально иной уровень сложности. Автор демонстрирует, как изменения в окружающей среде влияют на различные взаимосвязанные сообщества. Такое моделирование цивилизации, находящейся «под давлением», может рассматриваться как имплицитно-культурологическое исследование политической, социальной и культурной динамики. Важная этическая тема касается деградации наилучших идеологических принципов, если они перестают соответствовать изменившейся реальности. Образ общества, в котором социальные программы формируют значительный слой людей, которые никогда не работали, предугадывает одну из проблем современной цивилизации. Практически во всех изображенных в произведении социальных группах развивается такая защитная реакция на кризис как поиск забытья. Брекетт показывает разные варианты ухода от нестерпимого знания о неизбежной катастрофе: гедонистические попытки «жить одной минутой», тоталитарные религии и пр. Даже такая интеллектуальная деятельность как изучение истории может превратиться в навязчивое погружение в прошлое как способ бегства от настоящего и будущего. Таким образом, «Сага о Скейте» может рассматриваться как предупреждение о том, к чему могут привести некоторые тенденции современной (конец XX - начало XXI века) цивилизации, что отливает ее от многих антиутопий, чей футуристический антураж маскирует склонность описывать уже хорошо изученные социальные пороки, причем в фрормах, свойственным скорее первой половине $\mathrm{XX}$ века, чем нашим дням.

Ключевые слова: анти-утопия; научная фантастика; тоталитаризм; Ли Брекетт

The relevance of the theme. One of the functions of literature is modelling possible scenarios of social behavior. Sometimes they can become early-warning systems, singling out the negative tendencies that

(c) Kolesnyk O., 2019 
can cause problems in real life. The genre of anti-utopia is often seen in this context. However, many examples of this genre just describe variants of a totalitarian society of the first half of $X X$ ct. and fail to define principally new problems. This considerably reduces the prognostic potential. Moreover, the dystopic society is usually shown as a relatively small one, often lacking history. "The Book of Skaith" by Leigh Brackett is an example of a more complex approach to the theme.

The analysis of the literature. The modelling of social and political situation - both in fiction and in theoretical works - was in the focus of attention of many thinkers. We can find thoughts about utopia and anti-utopia in correlation with the ideology and social practice in works of K. Mannheim, $\mathrm{H}$. Marcuse, and P. Ricoeur. Ukrainian thinkers, such as Lesya Ukrainka, also payed attention to the theme in wide political and cultural context. O. Zabuzhko notices that works of I. Franko "... .already include in the compact form all the complex of critical ideas that would be later developed in the fiction in the genre of anti-utopia... : the total state control over a person, including the "statification" of the private life... the emergence of a new ruling caste... and as a result the complete social stagnation, accompanied by the ruthless oppression of the least attempts to change the status-quo (hence the permanent "inner war") $[2,128]$. The study of depiction of totalitarian practices in the genre of anti-utopia continues in the works of D. Martynov [3], A. Prykhodko [4], M. Shadurskiy [5], N. Voityna [1] and others.

The purpose of the research is to go beyond the strict borders of the genre of anti-utopia and to study the depiction of dystopic social system in a work of science fiction. The methodology. The main methods are hermeneutics and the comparative analysis. The scientific novelty. For the first time Leigh Brackett's work is researched as a sociological and culturological study with considerable prognostic potential.

The basic materials. The genre of literary utopia has such a long history, that it is difficult to find its beginning. Myths represent three main location of a blessed land: one spatial and two temporal. If the ideal is placed in time, it could be: 1) the first times of creation, when everything was still unsullied; 2) the final state of grace. In advanced religions, such as Christianity, we find both Eden at the beginning and New Jerusalem at the end. If the ideal is placed in space, we usually find some kind of Islands of the Blessed, that are difficult - but still possible - to reach.

The literary utopia often looks like a kind of reversion, reaching for more ancient - partly historical, partly mythical - way of life. Namely, Plato's "ideal state" is modeled not on the Egyptian social system (as it is often misinterpreted), but on the archaic Indo-European three-level stratification, still used in India in much more complicated variant. At the same time, Plato introduces the innovative conception that the ideal state can be made. Its social order is not dictated by gods or even by custom - on the contrary, the mythology should be consciously invented to bless the rationally invented new order. In this first theoretically grounded utopia, we already find contradictions. The first of them concerns opinions: what is ideal for one person is not ideal for another. The second concerns aims and means: is it possible to force person (or society) to be happy? Both contradictions are present in the majority of later utopias.

Re-thinking and re-evaluation can lead to the statement that Plato's "ideal state" is one of the first theoretical foundation of totalitarianism. The same applies to T. More and T. Campanella: it is now difficult even to evaluate their works dispassionately, as we live on the ruins of their dreams.

XX century saw mass disenchantment in the wisdom of leaders and in the goodness of science and technology. The genre of utopia was almost completely displaced by anti-utopia. While the logics of this change is understandable, the absence of belief in the future and of positive aim, is not an achievement to be proud of. Perhaps, a new utopia is bound to emerge.

It is often said that anti-utopias warn about the possible dangers and thus help to prevent them. It is not always the case. Mostly, they just exaggerate, and thus make more clearly seen, the already existing ills of a society. Nowadays anti-utopia is notably turning from philosophical essay into young adult fiction. The best examples combine entertainment with food for thought.

The descriptions of dystopic state differ, as every author strives for originality (for example, P. Reeve describes moving cities). Still, there are typical features: 1) the state is closed, without going in or out; 2) the ruling elite is a hermetic caste; 3 ) the society is rigidly stratified. A person is made to fit a certain place, without considering his or her desires or inclinations; 4) the state controls all the particularities, including private life and, sometimes, even thoughts (by means of information manipulation or direct intrusion); 5) there is no notion of human rights, the use of repressions is often arbitrary. To this basic "just injustice" any author can add some more specific unpleasantness - for example, shocking double standards, or even outright atrocities, such as The Hunger Games.

Such scheme is - unfortunately - quite life-like. Still, sometimes it seems that contemporary antiutopias reflect not so much the problems of our own world, as the canons of the genre. Some tropes seem more or less mechanically copied from the classics - works of Orwell, Zamyatin etc. - and from the political reality of totalitarian states of the early to mid XX ct. The life changes quicker than the staples of the genre. Even when authors describe futuristic technologies, their image of social relations is rooted in the past. That is why it is difficult to see them as warnings, able to prevent future problems.

Leigh Brackett is of the same generation as many great American science fiction writers. She was the wife of Edmond Hamilton, and a some-time co-worker of Ray Bradbury. Brackett was a co-writer of "Empire Strikes Back" script, which became her last work. Shortly before, she published "The Book of Skaith" 
trilogy (1976). It is a pity that excitant Russian translation does not justice to her exceptionally fine language, and Ukrainian translation is still nonexistent.

The book can be classed as the planetary romance. It is pure science fiction, although the type of the protagonist and the plot structure strongly tend to fantasy. Stark, the main hero, has single aim to find his foster-father, a representative of the Galactic Union, who was either killed or kidnapped on a hostile planet. He has no interest in changing the alien world. But the rebels of this planet choose him as his champion and he reluctantly joins forces with them.

As the Galactic Union itself is not described, we have no articulated example of utopia. It is enough to know that this organization is able to help residents of the dying planet to find a new world. Some of the residents had made this plea. But the local ruling elite has banned even the thought of a possible emigration. Hence the vanishing of an inconvenient alien.

The situation on the planet Skaith is defined by the fact that its sun is dying. For millennia the climate is getting colder, the resources are dwindling. Once on Skaith was a developed civilization, but it collapsed during the previous deterioration of climate. The following centuries saw the great Wandering - aimless and destructive roaming of peoples in search of habitable land. Human society has survived this terrible time because of the emergence of the Wandsmen, sworn to help the weak and feed the hungry. Since that time their heirs use principles akin to J. Bentham's utilitarianism: "Succor the weak, feed the hungry, shelter the homeless - striving always toward the greatest good of the greatest number" [6, 157]. However, the best principles, honestly practiced by noble men, can become more destructive than any corrupt power.

As the climate constantly deteriorates, the Wandsmen do everything to prevent the second Wandering and its atrocities. They can't help the final catastrophe, they just want to ensure that the people of Skaith would die with minimal suffering. So long so good. But when a chance of survival appears, they won't allow anybody to take it. For them, leaving the homeland is a blasphemy, and abandoning the socially dependent is a treachery that should be repressed.

So, as in most anti-utopias, we see a classical closed society. But it is not a homogeneous society of a typical anti-utopia. It is complex, multicultural and multiform. The ruling elite is a superstructure that oversees and controls the whole with minimal intervention. There are no such typical traits of anti-utopia as rigid stratification and total control of public and private life. Every person and every social organism is free to do anything - as long as it does not change the status-quo. After all, who would be able - and who would want - to test abilities or oversee opinions of every person on the globe? Compared to Brackett's scale, most antiutopias look like laboratory experiments.

It is easy for any writer to depict the ruling elite as self-serving, corrupt and lying. But Skaith is governed by ascetic, hard-working men, honestly devoted to their principles. Perhaps, the mode of government has not been bad in itself, but it was not able to cope with the changes. As the climate becomes colder, the harvests become ever poorer. Besides, waiting for Apocalypse changes the culture. People with no hope loose motivation to work and to care for the future. It such a situation there are several possible strategies: 1) to continue stoically toiling even without hope; 2) to believe in a miraculous salvation, 3) to lose awareness of the impending catastrophe by any means (drugs, totalitarian cults, complete loss of human reason).

The societies, controlled by the Wandsmen, can be roughly classified into some main groups.

The workers. These highly economically and politically developed nations live in the fertile zone. In spite of dwindling resources, they continue to provide food and other commodities for themselves and for all the population of the planet, as a considerable part of their production is taken away to be redistributed. Having no hope, they obey the system. But with the appearance of a chance of emigration, the people start rebellions.

The peripheral societies. Various barbaric nations and tribes, living in less favorable conditions beyond the fertile belt. They partially provide for themselves (productive work, trade, mercenary services), partially demand tribute from others, and partially receive dotation from the Wandsmen. Most of these groups are interconnected and interdependent, while some others are purely parasitic. As they cannot imagine any other way of life, they mostly stay apolitical, but can be swayed to help one of the main forces.

The Doom worshippers. There are three main types of the religion-centered societies: 1) those trying to ward off the end, prolonging the life of the Sun with blood sacrifices (a clear parallel with the Mesoamerican cults); 2) those praying for the miraculous salvation; 3) those who accept the end as inevitable and even desirable. All these cults and customs vary from unpleasant to shocking. Still, the author is far from condemning even most barbaric traditions. The only demarcation line is the ability of a group to choose life. "Anti-systems" (L. Gumilyov's term for the death-oriented societies) are condemned.

The Farers. When the social system of Skaith has crystalized, the Wandsmen provided for the weak and dispossessed. However, in the course of centuries, appeared a number of people, who were able to provide for themselves, but chose not to work. Their natural increase created generations who never worked in their life. In addition, there was constant influx, as many more people were seduced to leave their job, land and family, and live on a subsidy. The imminent end of the world brought to life many cults and customs, some of them ascetic, others - hedonistic, but all of them seeking oblivion.

In many aspects, the Farers are Hippie-like. They are "natural" in the sense of "just doing what you want". Here one can find free love, free drugs, exotic religions and unlimited self-expression (dance, music, 
body art etc.). As they never do anything productive, they are fed at the workers' expense. As they are completely dependent on the state charity, they are ready to do anything the Wandsmen want. The Farers are always ready to vandalize and spoil, and sometimes to kill. They are cheap and expendable, and in most cases can be used for repressive actions as well as any army. The depiction of Farers can be seen as a warning, very relevant in our days, when the idea of the consumer society is coming to a dead end.

The mutants. When Skaith had advanced technologies, the scientists experimented with controlled mutations, trying to make creatures better suited to the changing environment, and thus able to survive longer. This resulted in creation of half-beasts, well adapted to survival but with no trace of intellect or moral. Some of these races became man-eaters, and one of the greatest "natural" dangers of the planet. It is remarkable, that Brackett wrote this in 1974-1976, before the age of genetic engineering, M. Crichton' technothrillers and the development of the concept of transhumanism. Clearly, this is one more warning.

Among the mutant races there are two notable exceptions, who retained human mind and culture. The first of them is the people of the caves, well protected from the dangers of the world in "the womb of Skaith mother". They are historians, lovers of the past, unable to accept the actual reality. When they feel that changes in their world are inevitable, they decide to seal themselves in their dwelling, preferring slow death - but on their own terms. The second race is the winged people, unable to fly freely because of the faulty genetic engineering. They decide to welcome new possibilities and fight for their right to choose.

Just one hole in the iron curtain is enough to break this seemingly stable social super-system. The workers decide to emigrate. Trying to retain control, the Wandsmen ruthlessly repress all such attempts. Their reaction is irrational, as everybody knows that the planet is doomed. Unfortunately, this is quite realistic, as in human history there were plenty of irrational decisions made "for the good of the people". But the rebellion spreads and the whole system starts to collapse. The feared new Wandering begins, and there is no turning back for anybody.

In the Soviet science fiction there was a trope of the "export of revolution". The exploited masses on some faraway planet suffer in silence, and only ideologically competent Earthman can raise a social revolution. In Brackett's world, the locals are active, and they almost force the offworlder to become their leader. And - as opposite to contemporary anti-utopias four young adults - the revolutionaries are not a handful of young passionaries. The whole societies are ripe for rebellion.

Conclusion. In Leigh Brackett's "The Book of Skaith" we see not a typical for anti-utopia "island" society, but a whole planet. This implies a whole new level of complexity. The author shows how the changes in environment influence different interconnected societies. This modelling of civilization under pressure can be seen as an implicitly-culturological study of political, social and cultural dynamics. An important ethical topic concerns the degradation of the best ideological principles if they are not adapted to the changing reality. The image of society, where social programs breed a considerable strata of people who never worked is disturbingly relevant. Almost all depicted social groups develop such a protective reaction to the crisis as the search for oblivion. Brackett shows different variants of escaping from the unbearable knowledge of the impending catastrophe: hedonistic attempts of "living in a moment", totalitarian religions etc. Even such an intellectual activity as studying history can become an obsessive immersion in the past turns into a way of escaping the present. That is why "The Book of Skaith" can be viewed as a warning about the consequences of some tendencies of the contemporary (late XX - early XXI ct.) civilization. In this, it differs from many antiutopias, whose futuristic entourage masks the habit of depiction of the already well-known social ills, and in the forms more typical for the first half of the XX ct., than for our own days.

The final of "the Book of Skaith" is hopeful. However, the hope is in the possibility to emigrate from the doomed planet. We do not have a new world in reserve. Therefore, humankind must come to some consensus and save our own planet. For this, it is necessary to notice real dangers, not just entertain ourselves with fictional problems and fictional salvations. further study.

The legacy of Brackett - and the whole problematics of philosophy in the popular culture - is open to

\section{תimepamypa}

1. Войтина Н. М. До проблеми визначення жанру утопії та антиутопії. Волинь фрілологічна: текст і контекст. : Зб. наук. пр. Вип. 6: У 2-х ч. Ч. ІІ. Луцьк: РВВ “Вежа” Волин. нац. ун-ту ім. Лесі Українки, 2008. С. 33 - 39.

2. Забужко О. Філософрія української ідеї та європейський контекст: франківський період. К. : Факт, 2009. 156 с.

3. Мартынов Д. К рассмотрению семантической эволюции понятия «утопия». Вопросы фрилософии. 2009. № 5. С. 162-171.

4. Приходько А. М. Жанр "фэнтези" в литературе Великобритании проблема утопического мышления : дис. ... канд. филол. наук : 10.01 03. М., 2001. 199 с.

5. Шадурский М.И. Литературная утопия от Мора до Хаксли: Проблемы жанровой поэтики и семиосферы. Обретение острова. М.: Изд-во ЛКИ, 2007. 160 с.

6. Brackett L. The Book of Skaith. New York: Nelson Doubleday, 1976. 468 p.

\section{References}

1. Voityna N. (2008). About the problem of defining the genre of Utopia and Anti-utopia. The Philological Volyn'. Lutsk: Vezha [in Ukrainian]. Ukrainian].

2. Zabuzhko O. (2009) The Philosophy of Ukrainian National Idea in European Context: Franko's Period. Kyiv: Fact [in 
3. Martynov D. (2009). On the Semantical Evolution of the Notion of Utopi. Problems of Philosophy [in Russian].

4. Prykhodko A. (2001). The Genre of Fantasy in the British Literature: the Problem of Utopic Thinking. Candidate's thesis. Moscow: MGOPU [in Russian]

5. Shadurskiy M. (2007) Literary Utopia from More to Huxley: The Problems of the Genre Poetics and Semiosphere. Moscow: LKI Press [in Russian].

6. Brackett L. The Book of Skaith. New York: Nelson Doubleday, 1976 [in English].

Стаття надійшла до редакції 19.11.2018 p.

УДК 008:001

\author{
Копієвська Ольга Рафаїлівна \\ доктор культурології, професор, \\ завідувач кафедри арт-менеджменту \\ та івент-технологій \\ Національної академії керівних \\ кадрів культури і мистецтв \\ ORCID 0000-0002-4537-4888 \\ okopievska@gmail.ru
}

\title{
ТЕМАТИЗАЦІЯ КУЛЬТУРНИХ ПРАКТИК У НАУКОВОМУ ДИСКУРСІ
}

\begin{abstract}
Мета статті - дослідити наявні теорії щодо розуміння понять «практика» «культурна практика», їх осмислення в контексті модифікації й трансформації традиційних компонентів культури. Методологія дослідження включає загальнонаукові принципи систематизації та узагальнення досліджуваної проблеми, які дозволили визначити й науково обґрунтувати наявні теорії, концептуальні підходи до розуміння змісту поняття «практика» та «культурна практика». Мета та завдання статті обумовили застосування аксіологічного підходу, що дозволило виявити в розглянутих теоріях певну одностайність у розумінні приналежності людини до різноманітних практик, культурних зокрема. Використання аналітичного методу дозволило виявити концептуальні засади щодо подальших наукових перспектив. Наукова новизна полягає в дослідженні теорій щодо розуміння понять «практика», «культурна практика», з'ясування смислового діапазону досліджуваних понять, аналіз їхньої семантики й змістового наповнення. Висновок. Розглянуті в статті теорії дозволили констатувати, що головним суб'єктом будь-якої практики виступає людина, яка, здійснюючи будь-яку діяльність, утворює практику як певний набір властивих їй дій, яка заснована на її індивідуальних характеристиках, таких як поведінка, виховання, освіта, творчість, мистецтво, дозвілля, створення й підтримка традицій, ментальний зв'язок тощо. Однією з головних інтенцій культурних практик $є$ збереження, передача й подальший розвиток системи значень, смислів, уявлень, що опредмечені в знаннях та виражені в символічній формі. Тематизація культурних практик вимагає уточнення їхнього змістового наповнення й передбачає розробку понятійно-категоріального апарату, використання якого дозволить теоретично обґрунтувати й детально описати розробку алгоритму їхньої реалізації як сукупності дій, прийомів, методів, вербальної й невербальної комунікації як необхідного жестуального супроводу з урахуванням специфіки просторових локалів, топосів їхньої реалізації.
\end{abstract}

Ключові слова: практика; культурні практики; культурні повороти; культурні смисли; наукова традиція.

Копиевская Ольга Рафаиловна, доктор культурологии, профессор, заведующий кафедрой арт-менеджмента и ивент-технологий Национальной академии руководящих кадров культуры и искуссте

Тематизация культурных практик в научном дискурсе

Цель статьи - исследовать существующие теории относительно понимания понятий «практика» «культурная практика», их осмысления в контексте модификации и трансформации традиционных компонентов культуры. Методология исследования включает общенаучные принципы систематизации и обобщения исследуемой проблемы, которые позволили определить и научно обосновать существующие теории, концептуальные подходы к пониманию содержания понятия «практика» и «культурная практика». Цель и задачи статьи обусловили применение аксиологического подхода, что позволило выявить в рассмотренных теориях определенное однозначное понимание принадлежности человека к различным практикам, культурным в частности. Использование аналитического метода позволило выявить концептуальные основы относительно дальнейших научных перспектив. Научная новизна заключается в исследовании теорий относительно понимания понятий «практика», «культурная практика», выяснения смыслового диапазона исследуемых понятий, анализ их семантики и содержательного наполнения. Выводы. Рассмотренные в статье теории позволили констатировать, что главным субъектом любой практики выступает человек, который осуществляя любую деятельность образует практику как определенный набор свойственной для него действий, основанных на его индивидуальных характеристиках, таких как поведение, воспитание, образование, творчество, искусство, досуг, создание и поддержание традиций, ментальную связь и другое. Одной из главных интенций культурных практик является сохранение, передача и дальнейшее развитие системы значений, смыслов, представлений, опредмеченные в знаниях и выражены в символической форме. Тематизация культурных практик требует уточнения их содержательного наполнения и предусматривает разработку понятийно-категориального аппарата, использование которого позволит теоретически обосновать и детально описать разработку алгоритма их реализации как совокупности действий, приемов, методов, вербальной и невербальной коммуникации как необходимого жестуального сопровождения с учетом специфики пространственных локальных топосов, их реализации.

Ключевые слова: практика; культурные практики; культурные повороты; культурные смыслы; научная традиция.

Kopiyevska Olha, D. Sc. of Cultural Studies, professor, head of Department of Art-Management and Event Technologies, National Academy of Managerial Staff of Culture and Arts

Thematization of Cultural Practices in the Scientific Discourse

Purpose of the Article. The purpose of the article is to study the existed theories of the concepts of «practice» and «cultural practices». In addition, the author analyses their understanding in the context of the modification and transformation of the components of culture. Methodology. The methodology of the research consists of the general scientific principles of systematization and generalization. They allow the author to determine and substantiate the existing theory and the conceptual approaches to the understanding of

() Копієвська О. Р., 2019 